\title{
Basel IV Postponed: A Chance to Regulate Shadow Banking?
}

\author{
Katarzyna Parchimowicz \& Ross Spence*
}

\section{Abstract}

In the aftermath of the 2007 global financial crisis, regulators have agreed a substantial tightening of prudential regulation for banks operating in the traditional banking sector (TBS). The TBS is stringently regulated under the Basel Accords to moderate financial stability and to minimise risk to government and taxpayers. While prudential regulation is important from a financial stability perspective, the flipside is that the Basel Accords only apply to the TBS, they do not regulate the shadow banking sector (SBS). While it is not disputed that the SBS provides numerous benefits given the net credit growth of the economy since the global financial crisis has come from the SBS rather than traditional banking channels, the SBS also poses many risks. Therefore, the fact that the SBS is not subject to prudential regulation is a cause of serious systemic concern. The introduction of Basel IV, which compliments Basel III, seeks to complete the Basel framework on prudential banking regulation. On the example of this set of standards and its potential negative consequences for the TBS, this paper aims to visualise the incentives for TBS institutions to move some of their activities into the SBS, and thus stress the need for more comprehensive regulation of the SBS. Current coronavirus crisis forced Basel Committee to postpone implementation of the Basel IV rules - this could be perceived as a chance to complete the financial regulatory framework and address the SBS as well.

Keywords: Basel Accords, EU Law, shadow banking, financial stability, prudential regulation

\section{Introduction}

The autopsy of the 2007 global financial crisis has been a watershed moment for the way in which the financial sector functions. ${ }^{1}$ One of the most significant changes relates to the functioning of the banking sector. The traditional banking sector (TBS), which is subject to stringent prudential supervision under acts implementing the Basel Accords, consists of credit institutions granting loans and accepting deposits. ${ }^{2}$ However, this is not the only form of banking; there also exists another banking sector - shadow banking. ${ }^{3}$ The shadow banking sector (SBS), now dubbed 'the future of global finance', consists of a complicated web of entities, activities and transactions that, arguably, only 'Wall Street wizards' truly understand. ${ }^{4}$ There are numerous reasons why the SBS has risen to prominence; namely, through the evolution of prudential banking standards, the negative impact on profitability, the exploitation of regulatory arbitrage and new innovative financial products - which have all been key facilitators of the shift towards the SBS. $^{5}$

The aim of this study is to explore the significance of the most recent set of changes to the Basel III frame-

1. For an extensive analysis of reasons and (ongoing) consequences of global financial crisis see A. Tooze, Crashed: How a Decade of Financial Crises Changed the World (Viking 2018); A.S. Blinder, After the Music Stopped: The Financial Crisis, the Response, and the Work Ahead (Penguin Press 2013); National Commission on the Causes of the Financial and Economic Crisis in the United States, 'The Financial Crisis Inquiry Report' (2011), www.govinfo.gov/content/pkg/GPO-FCIC/pdf/GPOFCIC.pdf (last visited 2 January 2019).

2. Art. 4(1)(1), Regulation 575/2013 of the European Parliament and of the Council of 26 June 2013 on prudential requirements for credit institutions and investment firms and amending regulation (EU) No 648/2012 [2013] OJ L 176/1 known as Capital Requirements Regulation (CRR 575/2013).

3. Some commentators have argued that the TBS is now a 'back office activity'. See J. Cullen, 'The Repo Market, Collateral and Systemic Risk: In Search of Regulatory Coherence' in I.H.-Y. Chiu and I.G. MacNeil (eds.), Research Handbook on Shadow Banking Legal and Regulatory Aspects (Edward Elgar Publishing 2018) 85-92.

4. P. Mehrling, Z. Pozsar, J. Sweeney \& D.H. Neilson, 'Bagehot was a Shadow Banker: Shadow Banking, Central Banking, and the Future of Global Finance', Institute for New Economic Thinking, Discussion Paper 2013. See also, B. Gross, 'Beware Our Shadow Banking System', CNN Money (28 November 2007), http://money.cnn.com/2007/11/27/ news/newsmakers/gross_banking.fortune/ (last visited 28 December 2018).

5. Other issues that have contributed to the rise of shadow banking include regulatory changes, diversification, an increased demand for adaptable and novel financial products offering above market yields in low interest rate environments and specialisations. This article focuses on regulatory arbitrage. to And Centre for Law and Economics. Our deepest gratitude goes this paper, and to other participants of the seminar 'Bridging the Gaps in EU Financial Regulation' organised by the EURO-CEFG, the University of Warsaw, the University of Wrocław and the Young Researcher Group of the European Banking Institute (EBI) in 2018. Many thanks also to Edoardo Martino, Nathan de Arriba-Sellier and Shuai Guo for their feedback and insights. Finally, our gratitude goes to the anonymous referees for their comments and suggestions. All remaining errors are ours. 
work - the so-called Basel $\mathrm{IV}^{6}$ - both in relation to the rise of the SBS and in the context of current coronavirus-related developments. In doing so, we intend to demonstrate that ever more stringent regulation and supervision of the TBS without creating an analogous framework for the SBS is not going to make the financial system more stable. Our contribution will be structured as follows: Section 2 will explain the shadow banking phenomenon, from its origins to the struggle to accurately define it. Section 3 will describe the rise of the SBS by demonstrating that the impact of prudential regulation on profitability has resulted in the exploitation of regulatory arbitrage, leading to new forms of financial innovation. In that context, dichotomy between TBS and SBS and the previous Basel Accords will be discussed. This analysis will provide a crucial benchmark showing why market participants keep shifting their activities towards the less stringently regulated SBS. Section 4 will examine the specific example of Basel IV and the main novelties therein. Basel IV has arguably resulted in further debate, namely that the regulation of the TBS has deepened the resulting imbalance between the TBS and the SBS. However, its implementation has been postponed in order not to additionally burden banks dealing with the current coronavirus crisis. Could it be seen as a chance to correct what was omitted/add the SBS to the picture? Section 5 includes policy recommendations and concludes the discussion.

\section{Defining Shadow Banking}

\subsection{The Origins of Shadow Banking}

In 2007, at the annual economic policy symposium of the Kansas City Federal Reserve in Jackson Hole, Wyoming, American economist Paul McCulley coined the term 'shadow banking' to describe a system that posed a significant risk to financial stability because it was untouched by regulation, has lain hidden for years and operates on a subterranean level. ${ }^{7}$ Although 'shadow

6. Even though in official documents the BCBS is not using the title "Basel IV' for any of the amendments, in this article, for the sake of brevity, we will refer to Basel IV, meaning the set of changes completing Basel III standards proposed at the end of 2015 and in March/April 2016 and officially introduced in the document called 'Finalisation of Basel III'. See Basel Committee on Banking Supervision, 'Basel III: Finalising Post-Crisis Reforms', Bank for International Settlements (7 December 2017), www.bis.org/bcbs/publ/d424.pdf (last visited 28 December 2018). We hereby acknowledge that the use of the term 'Basel IV' is not fully justified, as this set of standards does not introduce groundbreaking changes in contrast to Basel I, Basel II and Basel III accordingly. However, it is commonly used in various analyses and papers and facilitates the receipt of this article. See, for instance, "Basel III to "Basel IV": What Changed?' Deloitte,https://www2.deloitte.com/mm/en/pages/risk/ articles/basel-iii-to-basel-iv.html (last visited 2 January 2019) or $M$. Imeson, “"Basel IV" Raises Capital Requirements Even Higher' Wolters Kluwer Insights (16 February 2018), www.wolterskluwerfs.com/article/ basel-iv-raises-capital-requirements-even-higher.aspx (last visited 2 January 2019)

7. P.A. McCulley, 'Teton Reflections', 2 PIMCO Global Central Bank Focus (2007) banking' is a relatively new term, the concept is not; the origins arguably go back to 19th century England, when Walter Bagehot wrote Lombard Street: A Description of the Money Market. ${ }^{8}$

Bagehot observed that London banks operated in parallel with financial firms known as 'bill brokers', who performed much the same functions as banks, but were not banks. Indeed, Bagehot noted that bill brokers were 'a special sort of banker who allow daily interest on deposits, and who for most of their money give security' as collateral to hedge risk. ${ }^{9}$ In modern day terms, Bagehot's definition of 'bill brokers', who performed the activity of converting bills into money, is very similar to what is known today as shadow banking. ${ }^{10}$ Yet Walter Bagehot is not the only commentator to recognise the importance of the SBS over the decades. There have been a host of other examples, ${ }^{11}$ one of which is described by Friedrich Hayek, who, in 1931, observed that

There can be no doubt that besides the regular types of circulating medium, such as coin, bank notes and bank deposits, which are generally recognised to be money or currency, and the quantity of which is regulated by some central authority... there also exists other forms of media of exchange... without being subject to any central control. ${ }^{12}$

\subsection{Defining Shadow Banking}

The fact that the SBS now accounts for a significant part of the financial system makes one wonder whether the term 'shadow banking' is 'pejorative'. ${ }^{13}$ Indeed, the term automatically implies a sector of dubious legality containing somewhat 'clandestine' and 'nefarious' connotations. ${ }^{14}$ Arguably, however, this explanation does capture the activities that played a large part in precipitating and exacerbating the financial crisis, such as excessive self-interest, corporate greed, poor governance, high leverage and regulatory arbitrage; this is potentially a reason for the ignominious reputation that SBS now has. ${ }^{15}$

8. W. Bagehot, Lombard Street: A Description of the Money Market (1873).

9. Ibid., at 28

10. M. Ricks, 'Regulating Money Creation after the Crisis', Harvard Law School 75, at 87-88 (2011). See also, A.M. Pacces and H. Nabilou, 'The Law and Economics of Shadow Banking', ECGI Working Paper Series in Law 2017:1 at 5 .

11. In 1993, the activity of what is known today as shadow banking was referred to as the 'parallel banking system'; see, generally, J.W. D'Árista and T. Schlesinger, 'The Parallel Banking System;', Economic Policy Institute Briefing Paper 1993; Mehrling, Pozsar, Sweeney \& Neilson, above n. 4, 1 at 1-2.

12. F.A. Hayek, Prices and Production (1931), at 113-114. See also, J. Sweeney, 'When Collateral is King', 1Credit Suisse, at 2-4 (2013).

13. M. Singh, 'The Economics of Shadow Banking', 5 Reserve Bank of Australia Conference Volume, at 22 (2013) (footnote 29).

14. J. Macey, 'It's All Shadow Banking, Actually', 31 Review of Banking and Financial Law 593, at 593 (2011-2012). See also, E. Lee, 'Shadow Banking System in China after the Global Financial Crisis - Why Shadow Banks Can Distort the Capital Market Order', 3 Peking University Law Journal 361, at 362-363 (2015).

15. E. McBride and S. Pignal, 'Shadow and Substance', The Economist (10 May 2014), www.economist.com/sites/default/files/20140510_ international_banking.pdf. 
How, then, can shadow banking be defined? The term 'shadow banking' is often used as a catch-all term to refer to a number of divergent institutions, instruments, markets and activities. Its amorphous nature has arguably become an obstacle to providing a clear and commonly accepted definition, the most commonly used one being that of the Financial Stability Board (FSB), which defines shadow banking as 'credit intermediation involving entities and activities outside the regular banking system'. ${ }^{16}$

The authors argue that trying to define shadow banking in such a broad and all-encompassing way is a fruitless endeavour. First, the scope of this definition is too wide; the purpose appears to be more for surveillance and monitoring than to provide an adequate workable definition. Second, this definition is not the most enlightening and raises more questions than it answers, questions, such as who the entities are and what activities comprise the SBS? ${ }^{17}$ Third, financial innovation and regulatory change across multiple jurisdictions ensure that the nature of the SBS is fluid and constantly evolving. It is therefore submitted that trying to define shadow banking using this broad approach will always be a challenge; identifying and summarising a complete set of characteristics that can apply to past, present and future shadow banking entities and activities may prove to be too difficult a task.

Instead, an alternative approach to defining 'shadow banking' could (and should) be adopted. A better approach may be to construct a definition in relation to the purpose for which shadow banking is used. For example, the purpose of this article will be to explore shadow banking as a market-based finance system that has its roots in the money markets. The money market is a market where transactions such as repos, securities lending and derivatives contracts facilitate collateralised finance; it is a market where long-term capital market assets are funded with short-term money market liabilities. 'Shadow banking' is, therefore, a 'market-based finance system' that provides an attractive funding alternative to that offered by the TBS. ${ }^{18}$

16. Financial Stability Board, 'Shadow Banking: Strengthening Oversight and Regulation', (27 October 2011) 1, www.fsb.org/wp-content/ uploads/r_111027a.pdf (last visited 28 December 2018). There are other examples too, such as The Bank of England, which defines shadow banking as "[i]nstruments, structures, firms, or markets which, alone or in combination, replicate, to a greater or lesser degree, the core features of commercial banks: monetary or liquidity services, maturity mismatch, and leverage" - see P. Tucker, 'Shadow Banking, Financing Markets and Financial Stability', Bank of England News Release (21 January 2010). The ECB defines shadow banking as'[a]ctivities related to credit intermediation, liquidity, and maturity transformation taking place outside the regulated banking system' - see K. Bakk-Simon, S. Borgioli, C. Giron, H. Hempell, A. Maddaloni, F. Recine \& S. Rosati, 'Shadow Banking in the Euro Area: An Overview', 133 ECB Occasional Paper Series April 2012: 1, at 5. This list is not exhaustive.

17. V. Lemma, The Shadow Banking System: Creating Transparency in the Financial Markets (2016), at 18. See also E. Lee, 'The Shadow Banking System - Why It Will Hamper the Effectiveness of Basel III', 008 University of Hong Kong Faculty of Law Research Paper 1 2015:13.

18. Other commentators have defined shadow banking in a similar way. For example, Alessio Pacces and Hossein Nabilou define shadow banking as '[l]everaging on collateral to support liquidity promises' - see
The aforementioned description can be described as 'functional'. A functional approach is able to unpack the economic purposes of the transactions used within the SBS. Such an approach is beneficial because it is intended to capture the complex practices through which money is created within the modern financial system. ${ }^{19}$ Exploring the SBS in this way, that is, through the lens of the transactions with which the SBS functions, requires a 'money view' ${ }^{20}$ The money view captures a distinctive element of the SBS: it is a marketbased finance system where debt relationships are organised via tradable securities. ${ }^{21}$

It is precisely the presence of collateral that gives the SBS its distinctive character. Collateral comes in the form of marketable financial assets and, depending on the liquidity of the collateral, implies the promise of cash immediacy without making much of a loss. Collateral can therefore be described as a mechanism that is designed to hedge default risk. It is a safety net that implies that should the borrower default, the collateral can be liquidated to make good on the promise. Collateral is the underpinning feature that makes such promises credible. As such, collateral is widely recognised as having the equivalence of 'money', 22 'cash'23 and 'quasimoney'. ${ }^{24}$ However, the implied liquidity of collateral, and the fact that it can be considered to be as safe as money, makes the contracts backed by the collateral, such as repos, securities lending and derivatives, subject to run, ${ }^{25}$ which was a fundamental issue during the recent financial crisis. ${ }^{26}$

Pacces and Nabilou, above n. 10, at 11. Another similar definition is provided by Daniela Gabor and Jakob Vestergaard, who state that shadow banking is defined as '[r]epo liabilities supported by tradable collateral' - see D. Gabor and J. Vestergaard, 'Towards a Theory of Shadow Money', Institute for New Economic Thinking Working Paper 2016:1, at 1

19. Gabor and Vestergaard, above n. 18.

20. P. Mehrling, 'Essential Hybridity: A Money View of FX', 41(2) Journal of Comparative Economics (2013).

21. Gabor and Vestergaard, above n. 18.

22. G. Yeowart, R. Parsons, E. Murray \& H. Patrick, Yeowart and Parsons on the Law of Financial Collateral (2016), at 155.

23. M. Singh, Collateral Reuse and Balance Sheet Space (2017), at 5.

24. E. Perotti, 'The Roots of Shadow Banking', 69 Policy Insight Centre for Economic Policy Research December 2013:1.

25. Pacces and Nabilou, above n. 10.

26. While the general consensus is that the SBS has no backstop to prevent 'runs', on recent views, it could be implied that there is, actually, some form of backstop. Therefore, two important developments should be mentioned at this juncture. First, on 16 March 2020, Rana Foroohar, of The Financial Times, noted that as a result of the coronavirus pandemic, 'central banks are backstopping the financial system with its repo operations, as banks exchange government bonds for cash' - this also includes the shadow banking system. On this, see R. Foroohar, 'How the Virus Became a Credit Run', Financial Times 1, at 17 (16 March 2020). Second, on 16 September 2019, the repo market experienced a liquidity shortage. The US Federal Reserve stepped in and provided a liquidity backstop by injecting more than $\$ 76$ billion to provide market participants with much needed cash. On this see The Economist, "Repo-market ructions were a reminder of the financial crisis" (26 September 2019); see also, G. Tett, 'The Repo Markets Mystery Reminds Us that We are Flying Blind', Financial Times (19 September 2019), www.ft.com/content/35d66294-dadc-11e9-8f9b-77216ebe1f17. 
2.3 The Makings and Scope of Shadow Banking Bearing in mind the origins of SBS, one could conclude that it comprises a varied set of entities, activities and transactions that function within the legal perimeter yet outside the confines of prudential bank regulation. Unlike the TBS, the SBS is not a single identifiable system but a constantly evolving network consisting of a varied and largely unrelated set of activities. The crux of the SBS is that it provides an alternative source of funding to that offered by the TBS. It provides funding by decomposing the process of credit intermediation into a sequence of discrete operations, pursued by very different types of financial market actors who interact across the wholesale funding market and rely on it for funding. ${ }^{27}$ In doing so, the SBS participates in the activity of credit intermediation by redistributing risk through credit, maturity and liquidity transformation, raising systemic risks, especially if combined with high leverage. It is through credit intermediation that shadow banks provide funding, as will be elucidated in what follows: ${ }^{28}$

1. Leverage: As opposed to using equity, leverage involves investing utilising borrowed funds;

2. Transferring credit risk: The purpose of transferring risk is to pass it from one party who does not want the risk to another party who is willing, for a fee, to take on the burden of risk;

3. Maturity transformation: Involves borrowing funds for short periods and investing or lending for longer periods; and

4. Liquidity transformation: The term 'liquidity' represents the ease with which an asset can be turned into cash. Liquidity transformation relates to assets, such as cash, which is used to invest in less liquid assets, such as bonds or derivatives.

The scope of the SBS is wide and varied. For example, participants in the SBS include a broad range of bank and non-bank financial intermediaries conducting various activities. Players typically include, but are not limited to, prudentially regulated banks, money market mutual funds (MMMF), credit hedge funds, investment banks, large financial institutions, private individuals, securitisation and special purpose vehicles. ${ }^{29}$ The transactions through which these entities carry out their activities are generally repos and securities lending and transactions. Although the SBS has many touchpoints, the scope of this article will focus on shadow banking from a transactional perspective.

27. S. Ghosh, I. Gonzalez del Mazo \& I. Otker-Robe, 'Chasing the Shadows: How Significant is Shadow Banking in Emerging Markets?', 88 The World Bank 1 (2012).

28. European Banking Authority, 'EBA Issues Final Guidelines on Institutions Exposures to Shadow Banking Entities and Recommends Approach to Limiting Risks', 15 December 2015, www.eba.europa.eu/-/eba-issuesfinal-guidelines-on-institutions-exposures-to-shadow-banking-entitiesand-recommends-approach-to-limiting-risks.

29. This list is not finite; in fact, virtually any entity operating in the financial system can conduct shadow banking in one way or another.

\section{The Rise of Shadow Banking}

How, then, has the SBS risen to prominence? There are four steps of reasoning, namely the imbalance in prudential regulation between the TBS and the SBS, resulting in a subsequent drop in profitability of the TBS and the ensuing exploitation of regulatory arbitrage, thereby facilitating financial innovation.

\subsection{Prudential Regulation}

In order to illustrate the regulatory imbalance between TBS and SBS, it is crucial to begin with the dichotomy in the functioning of these two sectors. Subsequently, the most relevant examples of prudential rules referring to TBS only, namely the Basel Accords, preceding Basel IV, shall be examined.

\subsubsection{The Dichotomy betmeen Traditional Banking and Shadom Banking}

Under the TBS, a bank is, among other things, an institution that grants loans and accepts deposits. Figure 1 depicts official banking and illustrates that the essence of traditional bank intermediation is deposit taking and loan making.

\section{Figure 1 Traditional Banking: Deposit Taking and Loan Making}

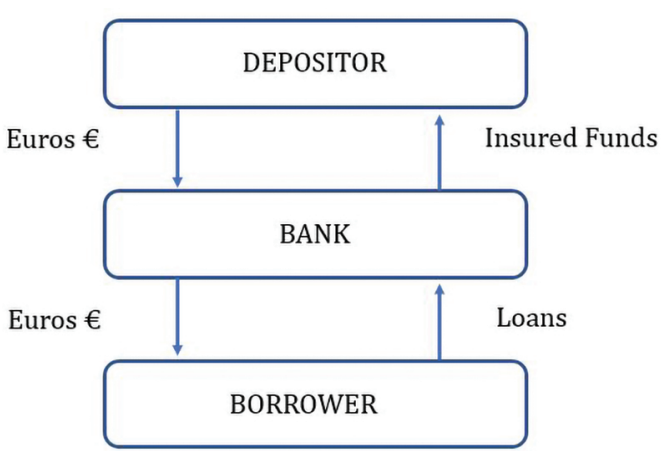

The logical starting point in the figure is that there is a depositor who deposits money with a bank. As long as the total deposited amount in the bank account is below the European Deposit Guarantee Scheme (EDGS) threshold of $€ 100,000$, the funds will be insured. ${ }^{30}$ The bank will then loan out these newly deposited funds to a borrower, who, for instance, requires money for a mortgage. In return, the asset the bank will receive, which will be collected upon over time, is the loan itself; this ensures that the bank will receive a recurring income stream for the life cycle of the loan. The bank itself is the essential component; it is the intermediary between the supply of funds from depositors and the demand for loans from borrowers. ${ }^{31}$

Demand deposits are, however, of no practical use to institutions and private individuals operating in the

30. Rec. 21 and 23 and Arts. 6(1) and (2) DGSD 2014/49.

31. R. Buckley, 'The Changing Nature of Banking and Why It Matters', in R. Buckley, E. Avgouleas \& D. Arner (eds.), Reconceptualising Global Finance and Its Regulation (2016) 9, at 9-20. 


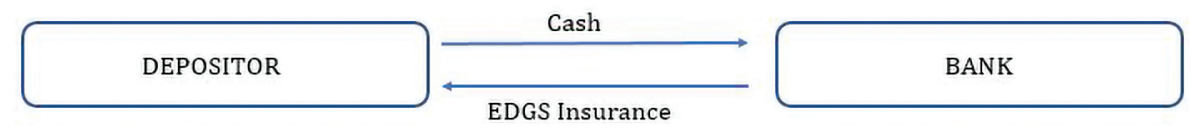

Shadow Banking Sector (Repo)*

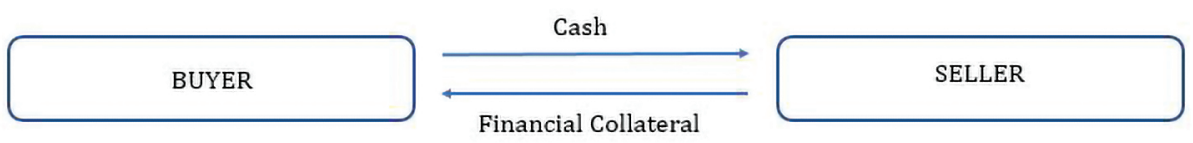

* A repo example has been used here but it could equally apply to securities lending and derivatives transactions.

SBS. ${ }^{32}$ The fact that these entities often 'deposit' large amounts of money for short periods ensures that the threshold would be exceeded and that anything above $€ 100,000$ is uninsured (and subject to bail-inable claims $^{33}$ ). This means that an entity depositing more than $€ 100,000$ in the TBS could face a capital loss should the bank face difficulties. ${ }^{34}$

Understandably, most market participants prefer riskfree liquid claims. As such, the SBS has created an alternative of demandable debt not subject to prudential regulation and credibly backed by a direct claim on liquidity. ${ }^{35}$ Within the SBS, when market participants want a safe place to house their capital, raise funds or borrow securities, they generally do so through the use of collateralised finance transactions. The SBS' distinctive liquidity guarantee arises from their issuing of collateralised financial credit in repo, securities lending and derivatives transactions. As illustrated by Figure 2, the SBS is functionally equivalent to the TBS because debt contracts in the SBS are backed by FC (financial collateral), just as debt contracts in the TBS are backed by the EDGS.

In both transactions outlined in the figure, the TBS and the SBS perform similar functions through 'maturity transformation'. The TBS engages in maturity transformation when it uses deposits (such as monthly wages), which are short-term, to fund loans (such as mortgages)

32. A. Krishnamurthy, 'How Debt Markets Malfunctioned in the Crisis', 24(1) Journal of Economic Perspectives 3, at 9-10 (2010).

33. The EDGS only insures deposits of up to $€ 100,000$ in the EU. Therefore, anything above this amount that is deposited within a credit institution becomes 'unsecured' and a 'bail-inable' claim should the bank fall into trouble. On this see Art. 44(2)(a) of the Bank Recovery and Resolution Directive 2014/59/EU (BRRD). A recent example of unsecured deposits being written down to zero was on 5 October 2015, where the Danish Bank 'Andelskassen JAK Slagelse' applied the BRRD - on this see the European Parliament, 'Bail-Ins in Recent Banking Resolution and State Aid Cases', (7 July 2016), www.europarl.europa.eu/RegData/etudes/ IDAN/2016/574395/IPOL_IDA\%282016\%29574395_EN.pdf.

34. Gabor and Vestergaard, above n. 18, at 10.

35. Perotti, above n. 24, at 1 . that are longer-term. ${ }^{36}$ The SBS does something similar through repo by raising short-term funds in the money markets secured with FC. The collateral taker can then use the acquired collateral to raise more cash and so on, thereby stimulating liquid and efficient markets. ${ }^{37}$

Generally, the maturity of a repo is overnight, with the debt contract rolled over (renewed) on a daily basis. This implies a confidence in immediacy because of its short maturity as it is routinely rolled over. ${ }^{38}$ In addition, Aaa government bonds are often used as FC to secure the repo, and the safety of the debt contract is dependent on the quality of the FC (and the applicable level of margin). Aaa government bonds are deemed to be of the highest quality, most liquid and therefore the safest form of FC as they are underpinned by a credible government. As such, it is generally unnecessary for market participants to do any due diligence on, or to determine the provenance of, the government bond because its value is known and accepted by all.

\subsubsection{Basel Accords before Basel IV}

As shown earlier, TBS and SBS play similar roles in the economy when it comes to funding and broader maturity transformation. However, the TBS is subject to prudential regulation, and many commentators argue that the evolution of prudential regulation, such as the Basel Accords, has inadvertently fuelled the growth of the SBS. ${ }^{39}$ In particular, the Basel Accords are both expensive and burdensome for banks, and regulators are essentially forcing banks to disclose information and hold minimum capital reserves. According to the Basel

36. See also Figure 1 for a visual depiction.

37. The collateral giver can then use the acquired cash to buy more securities (which are longer term).

38. The opposite is also the case where the buyer in the repo can demand his cash back by not rolling over the repo. See Perotti, above n. 24, at 1.

39. B. Baur and P. Wackerbeck, 'Into the Shadows: How Regulation Fuels the Growth of the Shadow Banking Sector and How Banks Need to React', European Financial Review (19 June 2013), www.europeanfinancialreview.com/?p=1065 (last visited 28 December 2018). 
Committee on Banking Supervision (BCBS), the aim of the Basel Accords is to:

Strengthen global capital and liquidity rules with a goal of promoting a more resilient banking sector. The objective of the reforms is to improve the banking sector's ability to absorb shocks arising from financial and economic stress, whatever the source, thus reducing the risk of spill-over from the financial sector to the real economy... The Committee's comprehensive reform package addresses the lessons of the financial crisis. Through its reform package, the Committee also aims to improve risk management and governance as well as strengthen banks' transparency and disclosures. Moreover, the reform package includes the Committee's efforts to strengthen the resolution of systemically significant cross-border banks. ${ }^{40}$

Subjecting the TBS to the Basel Accords has the effect of moderating financial stability by protecting and minimising the risk to depositors and governments. Yet from a commercial perspective, the Basel Accords are costly and burdensome because banks have to continually alter their business model to comply with incoming regulation, which ultimately impedes profitability. ${ }^{41}$ There is therefore an argument whether the Basel Accords are effective. Regulation is arguably effective when, on the one hand, risk is minimised, while on the other, benefits are maximised. ${ }^{42}$ Yet finding the optimal regulatory balance has proved to be 'something of a holy grail, highly desirable but illusory and difficult to achieve'. ${ }^{43}$

It has been widely argued that Basel I and II contributed to the 2008 financial crisis. ${ }^{44}$ In particular, the proliferation of off-balance sheet exposures and inadequate growth of banks' capital undermined Basel II's riskweighted capital regulation regime. Moreover, after this global downturn Basel III came into effect, which significantly amended Basel II and was aimed at preventing

40. Basel Committee on Banking Supervision, 'Basel III: A Global Regulatory Framework for More Resilient Banks and Banking Systems', (December 2010), www.bis.org/publ/bcbs189.pdf (last visited 28 December 2018).

41. Profitability will be discussed in greater detail later.

42. P. Fergusson, 'Regulation's Negative Effect on Productivity', Financial Times 8 (15 June 2018), www.ft.com/content/ 85c8578a-6d91-11e8-852d-d8b934ff5ffa (last visited 2 January 2019).

43. J. Bjorkholm and V. Johansson, 'Debt Versus Equity: In a Low Interest Rate Environment' (Master Thesis), at 3-4 (2015). See also, R. Pike and B. Neale, Corporate Finance and Investment: Decisions and Strategies (1993), at 325.

44. Basel II adopted several of the Basel I requirements. See F. Cannata and M. Quagliariello, 'The Role of Basel II in the Subprime Financial Crisis: Guilty or Not Guilty?', CAREFIN Research Paper No. 3/09, 2009:15, http://papers.ssrn.com/sol3/papers.cfm?abstract_id=1330417 (last visited 2 January 2019); A. Cornford, 'Revising Basel II: The Impact of the Financial Crisis and the Implications for Developing Countries', G-24 Discussion Paper Series No. 59 2010, https://unctad.org/en/Docs/ gdsmdpg2420102_en.pdf (last visited 2 January 2019); Provisions of Basel II are also often mentioned as contributing to the crisis in the comprehensive analyses of the 2008 downturn, see Tooze, above n. 1 , or A. Admati and M. Hellwig, The Bankers' New Clothes: What's Wrong with Banking and What to Do About It (Princeton University Press 2013). another crisis by reducing financial and economic stress and minimising the aftershock effects in the economy. ${ }^{45}$ Under Basel III, there are three specific requirements that can be argued as being significant. First, in the EU there is a capital adequacy regime requiring traditional sector banks to maintain a set minimum capital level of $8 \%{ }^{46}$ This means that banks operating in the TBS are required to hold a minimum ratio of capital to riskweighted assets (RWAs). By holding a percentage of deposits and equity on the balance sheet, the ultimate aim is to ensure the stability of the financial system by keeping the TBS solvent. Additionally, Basel III introduced a new countercyclical buffer, the aim of which is to incentivise banks to increase capital cushions when times are economically good and thus avoid the temptation to take more and more risk and invest all the capital for the highest gain possible owing to favourable economic conditions. In addition to these requirements, global systemically important banks (G-SIBs), as designated in accordance with the FSB's annual list and by national supervisors, are obliged to keep an additional buffer.

In order to calculate the capital a bank needs to hold against its assets, the Capital Requirements Regulation (CRR) describes how to weigh a bank's assets relative to risk. This phenomenon is the so-called RWAs. Assets that are safe and highly liquid, such as cash or gold, are disregarded from the RWAs regime, are considered risk free and have risk weight of 0 ; other assets that carry a higher risk, such as loans to other institutions, are assigned a higher risk weight. Then the amount of assets is multiplied by its risk weight, and the sum of all RWAs constitutes the denominator, whereas the amount of capital needed will be in the numerator. Consequently, the more risky assets the bank holds, the more capital it has to maintain. Capital comes in two forms: going concern and gone concern, each of which will be discussed in turn.

i. Going concern capital is the type of capital that has a loss absorbing capacity so that a bank can continue its activities and remain solvent. This type of capital is referred to as Tier 1 capital. Under Article 26 of the CRR, Tier 1 capital consists of both Common Equity Tier 1 capital (CET 1) and Additional Tier 1 capital (AT 1). CET 1 can be capital instruments, share premium accounts, retained earnings and other reserves. AT 1 capital is not defined in the CRR but must comply with Article 52 (1) of the CRR. For example, certain subordinated loans, hybrids and convertibles. $^{47}$

ii. Gone concern capital helps ensure that depositors and senior creditors can be repaid, should the bank fail. This type of capital is called Tier 2 capital and is defined under Article 71 of the CRR. Tier 2 capital

45. Basel Committee on Banking Supervision, above n. 40, www.bis.org/ publ/bcbs189. pdf (last visited 2 January 2019).

46. Art. 92(1)(c) of the CRR 575/2013.

47. Such as a contingent convertible bond ( $\mathrm{CoCo}$ ), which is a fixed income instrument that is convertible into equity if a prespecified trigger event occurs. 
consists of capital instruments, subordinated loans and share premium accounts. ${ }^{48}$

The minimum $8 \%$ capital requirement regime is composed of the following - 6\% Tier 1 capital, namely $4.5 \%$ of CET 1 and $1.5 \%$ of AT 1 ; and $2 \%$ Tier 2 capital. ${ }^{49}$ The G-SIB systemic buffer is prescribed individually according to the 'systemic importance level' of a given institution. The FSB awards points for each of the relevant categories, and G-SIBs are allocated into buckets using this score. The additional capital percentages vary from $1 \%$ for the lowest first bucket to $3.5 \%$ for the fifth one.

Second, an underlying feature of the global financial crisis was the build-up of excessive leverage in the TBS. In many cases, banks built up excessive leverage, while maintaining strong risk-based capital ratios. Basel III seeks to restrict this by encouraging banks to take initiatives to reduce their balance sheets by placing a limit on the size of activities a bank can develop compared with its own capital. To achieve this, a minimum leverage ratio has been proposed. ${ }^{50}$

Third, Basel III has introduced liquidity ratios. The first is the Liquidity Coverage Ratio (LCR). ${ }^{51}$ The objective of the LCR is to promote the short-term resilience of the liquidity risk profile of banks. It does this by ensuring that banks have an adequate stock of unencumbered high-quality liquid assets that can be converted immediately into cash to meet their liquidity needs for a 30 calendar-day liquidity stress scenario. ${ }^{52}$ The second is the Net Stable Funding Ratio (NSFR). ${ }^{53}$ The NSFR requires banks to maintain a stable funding profile in relation to the composition of their assets and off-balance sheet activities. A sustainable funding structure is intended to reduce the likelihood that disruptions to a bank's regular funding sources will erode its liquidity position in a way that would increase the risk of failure and potentially lead to broader systemic stress. ${ }^{54}$

Yet the Basel Accords, which are both a micro and macro prudential tool, refer to the TBS only - they do not apply to the SBS. ${ }^{55}$ In particular, the Basel Accords have adversely influenced banks by ultimately placing them at a competitive disadvantage compared with other non-prudentially regulated financial institutions. The TBS, whose primary aim is to maximise profits, have an incentive to circumvent the stringent prudential rules precisely because the Basel Accords are an impediment

48. Art. 63 of the CRR 575/2013.

49. Basel Committee on Banking Supervision, above n. 6, at 137, www.bis.org/bcbs/publ/dco424.pdf (last visited 2 January 2019). See also, M. Haentjens and P. De Gioia-Carabellese, European Banking and Financial Law (Routledge 2015), at 101-105.

50. Arts. $429-430$ of the CRR 575/2013.

51. Art. 412 of the CRR 575/2013

52. Haentjens and De Gioia-Carabellese, above n. 49. See also, Basel Committee on Banking Supervision, above n. 6, at 137, www.bis.org/bcbs/ publ/d424.pdf (last visited 2 January 2019).

53. Art. 428 of the CRR 575/2013.

54. Basel Committee on Banking Supervision, 'Basel III: The Net Stable Funding Ratio' (2014), www.bis.org/bcbs/publ/d295.pdf (last visited 2 January 2019).

55. Lee, above n. 17 to their primary function. The SBS, in particular, has proved to be a popular route for various entities because it is a sector that is subject to less stringent rules. This imbalance has given impetus to the development of the SBS because it continues to remain untouched by prudential standards. As mentioned earlier, the SBS 'performs much the same functions as traditional banking, but the names of the players are different and the regulatory structure is light... to non-existent.' 56

One could argue that SBS, owing to its close relationship with TBS, actually remains under some regulatory influence of Basel standards applicable directly to banks. It is indeed true that banks are often part of the same financial conglomerate as SBS entities, and many of the rules apply on a consolidated basis to all institutions within the conglomerate. Also, banks have to take into account exposures to SBS firms in their capital calculations. However, still many ways remain for the banks or the parent companies to avoid such 'indirect influence'. They could do it by establishing, for instance, special purpose vehicles (SPVs) or even subsidiaries, depending on the particular national legal regime. Also, the risk weights of SBS-stemming assets are rarely very low. Consequently, as long as SBS is not directly regulated in a prudential manner, the problem described in this contribution will persist.

It could also be contested that $\operatorname{repos}^{57}$ and securities lending transactions ${ }^{58}$ are regulated under the Securities Financing Transactions Regulation (SFTR). ${ }^{59}$ However, despite numerous publications identifying these transactions as a major source of systemic risk, it is unfortunate that this is an area yet to be substantially tackled. ${ }^{60}$ The SFTR, for example, aims to create a safer and more transparent financial system by placing additional requirements on market participants entering into

56. G. Gorton and A. Metrick, 'Regulating the Shadow Banking System', Brookings Paper on Economic Activity 261, at 261-262 (2010) (emphasis added).

57. Art. 3(9) of Regulation (EU) 2015/2365 of the European Parliament and of the Council of 25 November 2015 on transparency of securities financing transactions and of reuse and amending Regulation (EU) No $648 / 2012$.

58. Arts. 3(7) and (11)(a) and (b) of Regulation (EU) 2015/2365 of the European Parliament and of the Council of 25 November 2015 on transparency of securities financing transactions and of reuse and amending Regulation (EU) No 648/2012.

59. Regulation (EU) $2015 / 2365$ of the European Parliament and of the Council of 25 November 2015 on transparency of securities financing transactions and of reuse and amending Regulation (EU) No 648/2012.

60. V. Constancio, 'Margins and Haircuts as a Macroprudential Tool', VicePresident of the ECB, at the ESRB international conference of the macroprudential use of margins and haircuts (6 June 2016), www.esrb.europa.eu/news/speeches/date/2016/html/ sp160606.en.html. See also, Financial Stability Board, 'Global Monitoring Report on Non-Bank Financial Intermediation 2018', (4 February 2019), 1 at 25, www.fsb.org/wp-content/uploads/P040219.pdf; D. Heremans and A. Pacces, 'Regulation of Banking and Financial Markets', in R.J. Van Den Bergh and A.M. Pacces (eds.), Regulation and Economics (2012) 558, at 560; M. Raffan and J. Benjamin, 'Wholesale Markets and the Limits of Regulation', International Financial Law Review 1, at 1 (2014); M. Thiemann, M. Birk \& J. Friedrich, 'Much Ado About Nothing? Macro-Prudential Ideas and the Post-Crisis Regulation of Shadow Banking', Kolner Zeitschrift fur Sozialpsychologie 259 (2018). 


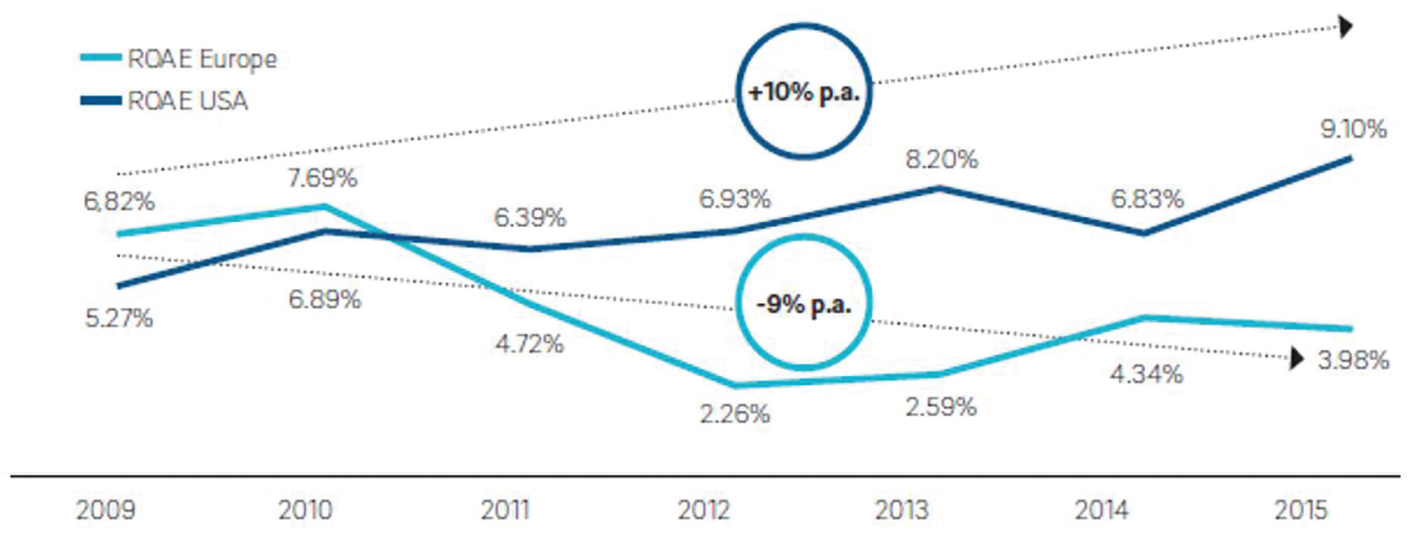

securities financing transactions. The approach taken by the SFTR requires securities financing transactions to adhere to:

- The reporting requirement: securities financing transactions must be reported to trade repositories, ${ }^{61}$

- The disclosure requirement: transparency and disclosure obligations by Undertakings for Collective Investment in Transferable Securities Directive (UCITS) management companies, UCITS investment companies and Alternative Investment Fund Managers (AIFMs) requiring periodic reports informing investors of securities financing transactions and total return swaps; ${ }^{62}$ and

- The collateral reuse requirement: prior risk disclosure and written consent before counterparties are permitted to reuse or re-hypothecate assets. ${ }^{63}$

However, commentators remain sceptical, arguing that the SFTR does no

more than provide another red flag in a sea already full of flags... The principles are noble but when there is so much regulatory change in the market, surely the goal should be to focus

on the implementation of tangible and meaningful reforms. ${ }^{64}$

So the fact that regulation in the SBS is not as comprehensive (or direct) as the TBS, and the fact that the SBS performs very similar functions to the TBS, places the SBS at a competitive advantage precisely because credit intermediation is performed outside the prudential regulatory framework. This competitive advantage becomes particularly acute when it is discovered that the

61. Art. 4 of Regulation (EU) 2015/2365 of the European Parliament and of the Council of 25 November 2015 on transparency of securities financing transactions and of reuse and amending Regulation (EU) No $648 / 2012$.

62. Arts. 13 and 14 of Regulation (EU) 2015/2365 of the European Parliament and of the Council of 25 November 2015 on transparency of securities financing transactions and of reuse and amending Regulation (EU) No 648/2012.

63. Art. 15 of Regulation (EU) 2015/2365 of the European Parliament and of the Council of 25 November 2015 on transparency of securities financing transactions and of reuse and amending Regulation (EU) No 648/2012.

64. T. Dilks and A. Datoo, 'Danger Signs', Lexology 1, at 2 (2016). net credit growth of the economy since the global crisis has come from the SBS rather than traditional banking channels. ${ }^{65}$ As such, the importance of the SBS to the economy as a whole cannot be overemphasised. However, crucial to the continued growth of the economy, and the stability of the SBS, there are calls for regulation and effective oversight, in the hope of preventing another global economic meltdown. ${ }^{66}$

\subsection{Profitability}

The further step in the rise of the SBS relates to profitability. While it is not disputed that the tightening of prudential regulation strengthens the resilience of the TBS, the flipside is that it does so by limiting the profitability of the TBS. The upward trajectory of forcing the TBS to strengthen capital and liquidity has the paradoxical effect of negative trajectories for banks' profitability in the EU. A recent study by Roland Berger (see Figure 3) demonstrates that the profitability of EU banks, as compared with that of US banks, has decreased by $9 \%$ between 2009 and 2015. This drop in profitability poses a real challenge for European banks, considering the low interest rates, economic growth and, significantly, regulatory pressure and the associated costs. $^{67}$

While there is currently no empirical evidence for a causal relationship between regulatory pressure and profitability, along with many other factors that have contributed to a decrease in profitability, such as the

65. R. Davies, 'The Moonshine of our Times: The Global Rise of Shadow Banking', The International Economy 70, 71 (2015). See also, S. Calimani, G. Halaj \& D. Zochowski, 'Stimulating Fire-Sales in a Banking and Shadow Banking System', 46 ESRB Working Paper Series (June 2017).

66. Financial Stability Board, 'Global Shadow Banking Monitoring Report 2015', (12 November 2015), 2. See also, Financial Stability Board, 'Policy Framework for Strengthening Oversight and Regulation of Shadow Banking Entities', (29 August 2013), www.fsb.org/wp-content/ uploads/r_130829c.pdf (last visited 2 January 2019); Z. Liansheng, 'The Shadow Banking System of China and International Regulatory Cooperation', Centre for International Governance Innovation 1, at 10 (2015).

67. T. Quesnel, M. Pfeiffer \& D. Johner, 'Implications of Ongoing “Basel IV" Debates', Roland Berger 1, at 4 (2017). See also, S. Schneider, G. Schrock, S. Koch \& R. Schneider, "Basel "IV": What's Next for Banks?', Global Risk Practice (2017); L. Amorello, 'Beyond the Horizon of Banking Regulation: What to Expect From Basel IV', 58 Harvard International Law Journal 21, at 37 (2016). 
Eurozone crisis, this drop in profitability implies that regulatory pressure and the associated costs pose a real challenge for EU banks (see Section 4.3).$^{68}$ As explained further on, Basel IV may contribute to the overall regulatory burden by increasing the capital requirements in the arbitrary way of an output floor and restricting the use of the IRB. Such a situation may ensure that profits could continue to plunge. Sinking profitability constitutes a significant incentive for the TBS to migrate activities to the less regulated SBS. ${ }^{69}$

\subsection{Regulatory Arbitrage}

A third aspect in relation to the rise of the SBS is regulatory arbitrage. Given that the TBS is so heavily regulated, consequently impeding profitability, it is unsurprising that there is an incentive to circumvent the rules by exploiting regulatory arbitrage and migrating activities to the SBS. $^{70}$ Regulatory arbitrage can be defined as the restructuring of financial activities to circumvent burdensome regulation. The central issue is that as regulation within the TBS tightens, by default the SBS will continuously gain traction. This argument becomes particularly acute when we discover that

it takes roughly two hours to assemble a team of finance geeks and lawyers to devise a product or transaction that will bypass any new rule or regulation coming our way. ${ }^{71}$

According to Charles Goodhart, effective regulation of the TBS is indeed very difficult to achieve. There is a pertinent argument that regulation of the TBS is selfdefeating because there will always be a way to circumvent the rules. ${ }^{72}$ The regulation of the TBS is selfdefeating because of the so-called boundary problem. The boundary problem holds that as one level of the TBS becomes regulated, or starts the process of regulation, there is an incentive for financial market actors to scramble over the boundary into the less stringently regulated SBS to conduct business. Owing to a continual drive to maximise profits, the boundary problem then becomes perpetual because as regulation imposes new

68. Amorello, above n. 67.

69. Davies, above n. 65, at 70-72.

70. G. Buchak, G. Matvos, T. Pskorski \& A. Seru, 'Fintech, Regulatory Arbitrage, and the Rise of Shadow Banks', 130(3) Journal of Financial Economics 453 (2018). See also, D. Nuoy (Chair of the Supervisory Board of the ECB), 'Gaming the Rules or Ruling the Game? - How to Deal with Regulatory Arbitrage', (15 September 2017), www.bankingsupervision.europa.eu/press/speeches/date/2017/html/ ssm.sp170915.en.html.

71. A. Nesvetailova, 'The Evolution of Nowhere Banking', Risk \& Regulation 6, at 6-7 (Spring, 2014)

72. C. Goodhart, 'The Emerging New Architecture of Financial Regulation', Centre for Financial Studies Working Paper 2011:1, at 25, www.econstor.eu/bitstream/10419/57352/1/657391263.pdf (last visited 2 January 2019). See also, C. Goodhart, The Central Bank and the Financial System (Palgrave Macmillan 1995), at 337; P. Drysdale, Reform and Recovery in East Asia (Routledge 2003), at 40; L. Baxter, 'Baxter Discusses Financial Regulation in Europe, Asia', Duke Law News (12 October 2012), https://law.duke.edu/news/baxter-discussesfinancial-regulation-europe-asia/ (last visited 2 January 2019); A.G. Haldane, 'Constraining Discretion in Bank Regulation' (9 April 2013) speech given at the Federal Reserve Bank of Atlanta 14. costs and burdens, it will consequently facilitate regulatory arbitrage. ${ }^{73}$

There is not only an economic significance correlated with regulatory arbitrage, but also geographical significance. For example, low-tax or no-tax jurisdictions are regularly exploited to take advantage of tax, regulatory, legal and administrative features inherent in these jurisdictions. ${ }^{74}$ As such, the SBS has a global reach because the sectors' activities span across geographical jurisdictions, which results in cross-border implications. ${ }^{75}$ Different regulatory and legal frameworks across various jurisdictions potentially provide a safe harbour for the SBS to arbitrage the rules because of the difficulty in monitoring or curbing the activities that spread across the globe. ${ }^{76}$

\subsection{Financial Innovation}

The final aspect of the rise to prominence of the SBS is the development of financial innovation. While many commentators view regulatory arbitrage as a negative, regulatory arbitrage can also be viewed positively as it facilitates financial innovation by creating new ways to conduct business. The SBS is a case in point, given that there is now a genuine economic demand for services conducted in the SBS. Competition from financial firms specialising in niche markets offering an above market yield has allowed financial innovation to flourish, resulting in an increased demand for novel and adaptable financial products. Many entities, activities and transactions operating in the SBS now have valid and valuable economic and financial market functions. The SBS is, indeed, a hotbed of innovation. It is unstifled by the rules, and the growth of the SBS may be understood as one consequence of evolving legal and regulatory structures stemming from the TBS. ${ }^{77}$

\section{Basel IV: Another Brick in the Wall}

\subsection{Basel IV - Main Novelties}

The most recent Basel Accord, Basel IV, is complementary to Basel III in that Basel IV was introduced to repair the omissions of Basel III. By doing so, Basel IV 'now completes the global reform of the regulatory

73. C. Goodhart, Too Important to Fail - Too Important to Ignore (Parliament Publications, House of Commons 2010), at 11

74. For example, the Cayman Islands, Jersey, Ireland, Luxembourg and the Netherlands. On this see J. Deacon, Global Securitisation and CDOs (Wiley 2004), at 46

75. R. Gandhi, 'Danger Posed by Shadow Banking Systems to the Global Financial System - The Indian Case', International Conference on Governance \& Development: Views from G20 Countries 1, at 4-5 (2014), www.bis.org/review/r140827b.pdf (last visited 2 January 2019). See also, P.R. Wood, Project Finance, Securitisation and Subordinated Debt (Sweet\&Maxwell 2007), at 6-014-6-017.

76. E. Lee, 'Shadow Banking System in China After the Global Financial Crisis', 024 University of Hong Kong Faculty of Law Research Paper 1 2015:1-2, http://papers.ssrn.com/sol3/papers.cfm?abstract_id= 2631343 (last visited 2 January 2019).

77. M. Singh, Collateral and Financial Plumbing (RISK 2016), at 35-39. 
framework which began following the onset of the global financial crisis. ${ }^{78}$ It also constitutes the most recent global regulatory initiative, the consequences of which boost the further expansion of the SBS sector.

Under Basel III the most important requirement is arguably that of capital adequacy, which is reliant on the amount of RWAs. However, the issue of how RWAs were to be calculated had never been comprehensively regulated in any of the Basel Accords. ${ }^{79}$ Banks could either apply the standardised approach $(\mathrm{SA})$ on the basis of risk weights determined by the supervisors or recognised credit rating agencies or use the internal ratingsbased model (IRB), which allows the banks themselves to establish their own criteria for risk-weighting. This choice was left to the banks' discretion. In practice this means that banks could have a direct influence on the final level of the required regulatory capital. It seems hard to find a better incentive for gaming such a calculation process. ${ }^{80}$ The Economist called the IRB resulting capital 'do-it-yourself capital'. ${ }^{81}$ The significant variation in RWAs across banks with very similar portfolios only served to justify that nickname. ${ }^{82}$ Basel IV aims to solve this problem by 'restoring credibility in the calculation of RWAs and improving comparability of banks' capital ratios. ${ }^{83}$

Basel IV introduces four main novelties. First, the use of IRB to calculate credit risk $^{84}$ has been banned with respect to specific types of exposures. In the case of equity, only the $\mathrm{SA}$ is permitted. In turn, the risk weight of exposures to banks and other financial institutions, as well as particular corporates, ${ }^{85}$ should not be estimated using the advanced IRB, while the foundation $\mathrm{IRB}$ variation is permissible. ${ }^{86}$

78. Mario Draghi quoted in C. Binham, M. Arnold \& C. Jones, 'New Basel Rules on Capital Hit European Banks', Financial Times (7 December 2017), www.ft.com/content/ec3fb98e-db67-11e7-a039c64b1c09b482 (last visited 2 January 2019).

79. Basel I praised the SA, but then it changed, and in both Basel II and III regulators left some discretion regarding the choice of either the standardised or the internal approach. As a result, banks were able to decide how to calculate RWAs and, therefore indirectly, how much capital to hold.

80. For an in-depth analysis of how and why RWAs calculations vary see V. Le Leslé and S. Avramova, 'Revisiting Risk-Weighted Assets. Why Do RWAs Differ Across Countries and What Can Be Done About It?', IMF Working Paper 12/90 (2012), www.imf.org/external/pubs/ft/wp/ 2012/wp1290.pdf (last visited 2 January 2019).

81. 'DIY Capital', The Economist (8 December 2012), www.economist.com/news/finance-and-economics/21567958-edificemodern-bank-regulation-comes-under-scrutiny-diy-capital (last visited 2 January 2019).

82. R. Turk-Ariss, 'Heterogeneity of Bank Risk Weights in the EU: Evidence by Asset Class and Country of Counterparty Exposure', IMF Working Paper 17/137 (2017), www.imf.org/en/Publications/WP/Issues/ 2017/06/09/Heterogeneity-of-Bank-Risk-Weights-in-the-EU-Evidenceby-Asset-Class-and-Country-of-44965 (last visited 2 January 2019).

83. Basel Committee on Banking Supervision, 'Finalising Basel III IN BRIEF', (2017), https://www.bis.org/bcbs/publ/d424_inbrief.pdf (last visited 2 January 2019).

84. Credit risk is the risk linked directly with lending. It refers to the potential loss caused by a borrower defaulting on its debt repayment.

85. Corporates belonging to groups with total consolidated revenues exceeding EUR 500m.

86. Advanced IRB relies exclusively on the data and procedures established internally by the given bank. In contrast, foundation IRB is partially
Second, owing to the high level of unpredictability borne by operational risk, ${ }^{87}$ the only method to quantify such risk is by utilising the SA. Internal models have been assessed as too unreliable in this regard. ${ }^{88}$ Certainly, SA is able to increase comparability between institutions and the level playing field in this regard. On the other hand, given the vast disparities between modern banking business models, it can be harmful to some of them, imposing a 'one size fits all' policy.

The third novelty completes the risk-dependent capital adequacy framework for G-SIBs with a new risk-independent requirement. It imposes a special extra leverage ratio on G-SIBs 'to maintain the relative incentives provided by both [risk-weighted and risk-independent K.P.] capital constraints' ${ }^{89}$ The final leverage ratio these entities have to meet is a sum of a base $3 \%$ requirement and a half of risk-weighted higher-loss absorbency requirement as determined annually by the FSB. For instance, according to the 2019 FSB list, ${ }^{90}$ Citigroup is placed in bucket no. $3(2 \%)$. Thus, it will be obliged to meet the leverage ratio buffer at the level of $4 \%(3 \%+0.5 \times 2 \%)$.

Fourth, and arguably the most controversial requirement included in the Basel IV package, is the introduction of the output floor. It is a fixed level of all RWAs calculated using the SA, below which the amount of RWAs based on the IRB cannot fall. The threshold chosen is $72.5 \%$ of RWAs calculated with the SA. For instance, if the bank uses the IRB to count its RWAs, then the resulting amount cannot be lower than $72.5 \%$ of this bank's RWAs calculated using the SA:

IRB-based calculation $\geq 72.5 \%$ of SA-based calculation.

If the IRB-based calculation falls below $72.5 \%$ of the SA-based calculation, the bank is obliged to use the $72.5 \%$ of the SA-based result as its RWAs amount in the process of calculating the required regulatory capital to be held.

However necessary these reforms sound, its final shape is far from perfect. Neither 'restored credibility' nor 'facilitated comparability' 91 that regulators aim for is entirely worth the price that the EU banks will have to pay to comply with those requirements. Most importantly, the negative consequences to be expected in con-

dependent on supervisors' recommendations. Advanced IRB is the form of internal model that allows the bank to calculate internally probability of default, loss given default and exposure at default, while by Foundation IRB only probability of default can be calculated internally, when the rest of the factors are based on pre-established values.

87. Operational risk refers to broadly understood operations that a bank undertakes. Losses could be incurred, for instance, by some internal procedural failure or even by external factors.

88. BCBS (n. 83)

89. Basel Committee on Banking Supervision, 'High-Level Summary of Basel III Reforms', (2017), www.bis.org/bcbs/publ/d424_hlsummary.pdf (last visited 2 January 2019).

90. Financial Stability Board, '2019 List of Global Systemically Important Banks (G-SIBs)', (22 November 2019), www.fsb.org/wp-content/ uploads/P221119-1.pdf (last visited 30 May 2020).

91. $\operatorname{BCBS}$ (n. 83) 
nection with the implementation of these rules could result in an exodus into the less regulated SBS.

\subsection{Basel IV - General Consequences}

\subsubsection{Regulatory Capital}

Even though one of the main articulated promises concerning Basel IV was no increase in capital requirements, ${ }^{92}$ it is probable they will rise indirectly as a result of the change in the models' regime and output floors. Already after the announcement of the proposal, many analyses $^{93}$ delivered data concerning the future amount of required capital. The exact numbers vary, but all of the reports have one thing in common - they conclude that the increase will take place and be noticeable for banks. According to statistics from the BCBS (which is one of the more optimistic prognoses ${ }^{94}$ ), internationally active banks will experience a capital shortfall of EUR 90.7 billion. ${ }^{95}$ European Banking Authority's assessment differs drastically - according to the watchdog capital, the shortfall at the EU's largest banks would reach EUR 135 billion. ${ }^{96}$

To comprehend why banks will be obliged to gather more capital, it is crucial to stress the interdependency between final capital requirements and models of RWAs calculation. As the Basel IV reform limits the use of the IRB approach, known for being more accurate and more institution tailored, banks will be forced to rely on the SA models, constructed by their supervisors. That, combined with an automatically triggered output floor, means an increase of the RWAs amount constituting denominator in the capital buffers' calculation. An increase in the denominator means a decrease in the overall result. Thus, banks holding the same amount of equity/deposits as before Basel IV will suddenly find themselves in breach of capital requirements. Consequently, the capital that banks are expected to have at their disposal will have to rise, even though the require-

92. E. Price, 'Operational Risk Framework Hints at Basel IV', International Financial Law Review (21 March 2016), www.iflr.com/Article/ 3539581/Operational-risk-framework-hints-at-Basel-IV.html (last visited 2 January 2020).

93. 'Basel IV: Big Bang - Or the Endgame of Basel III? BCBS Finalises Reforms on Risk Weighted Assets (RWA)', PWC Analysis (December 2017), www.pwc.com/sg/en/publications/assets/basel-iv-big-bang-orendgame-of-basel-iii-201712.pdf (last visited 2 January 2019); UBS reports and UniCredit estimates quoted in 'The Revised Basel BankCapital Standards are Complete at Last', The Economist (14 December 2017), www.economist.com/finance-and-economics/2017/12/14/therevised-basel-bank-capital-standards-are-complete-at-last (last visited 2 January 2020).

94. For instance, McKinsey \& Company estimates the capital shortfall to be around EUR 120 billion. See S. Koch, R. Schneider, S. Schneider \& G. Schröck, 'Bringing Basel IV into Focus', McKinsey (November 2017), www.mckinsey.com/business-functions/risk/our-insights/bringingbasel-iv-into-focus (last visited 2 January 2020).

95. B. Groendahl, N. Comfort, S. Brush \& E. Robinson, 'Banks Emerge Winners from Final Post-Crisis Capital Rules', Bloomberg (8 December 2017), www.bloomberg.com/news/articles/2017-12-08/banks-breathsigh-of-relief-as-basel-deal-limits-capital-impact (last visited 2 January 2019).

96. See EBA's press release from 2 July 2019, https://eba.europa.eu/ebabasel-assessment-sees-impact-driven-by-large-banks (last visited 15 April 2020). ments themselves will stay the same. Banks' representatives point to the severe methodological flaws in this logic, linked to the fact that half of the whole capital increase will stem from output floors, ${ }^{97}$ which were designed as a safety valve for correct RWA calculations, not the main source of capital burden. Banks also stress the probability that they will be overcapitalised.$^{98}$ However, this argument from their side has been constantly repeated since the first Basel III capital ratios were announced.

There are still two valid threats that the frozen capital could turn into reality. First, when banks need to raise capital, they usually take on more debt, limit their lending activities and make credit expensive. ${ }^{99}$ Such deterrence from providing credit to the economy could further result in an adverse impact on growth. ${ }^{100}$ Second, the other way of achieving the required capital threshold is to lower the return on equity (RoE). Analyses have already demonstrated that owing to the Basel IV rules, RoE could fall by $0.6 \%$ in the whole European banking sector. ${ }^{101}$ This amount might not seem significant, but profit-oriented investors are beginning to regain trust in banks, which this decrease could easily undermine. Regulators are well aware of those threats, which was proven by their reaction to postpone Basel IV implementation triggered by the coronavirus crisis (see Section 4.3.).

\subsubsection{More Risk and Deepened EU Fragmentation}

One of the main aims of the Basel IV reforms was to improve risk-dependent calculations, to limit manipulative tendencies in the risk assessment and thus make the whole system less risky. Paradoxically, it might turn the other way around. Usually, banks assess the risk of borrowers ${ }^{102}$ and try to be as risk averse as possible or adjust the interest rate accordingly. However, Basel IV's output floor will impose an amount of RWAs, even if their own IRB calculations come up with a lower result. The banks will lose their main incentive to pick less ris-

97. As Christian Ossig of Association of German Banks pointed out during the 'Basel III: Are we done now?' Conference in Frankfurt am Main (29 January 2018), the rise of capital caused by output floor amounts to $6.6 \%$, which is half of the total $12.9 \%$ overall increase in capital requirements.

98. See the remarks of James von Moltke, chief financial officer at Deutsche Bank, in 'Bankers Welcome Final Basel III Rules Through Gritted Teeth', Euromoney (13 December 2017), www.euromoney.com/article/ b1611h1m2w×315/bankers-welcome-final-basel-iii-rules-throughgritted-teeth (last visited 2 January 2020).

99. Raising equity as a means of increasing capital is still arbitrarily considered to be much more expensive than borrowing, mainly in view of the tax-deductability of interest rates' costs. See Admati and Hellwig, above n. 44 .

100. See 'Basel IV', Banking\&Insurance Sia Partners (30 January 2017), http://en.finance.sia-partners.com/20170130/basel-iv (last visited 2 January 2020) or A. Kröner and C. Wallace, 'A New Pain Threshold for Banks', Handelsblatt Global (11 October 2017), https:// global.handelsblatt.com/finance/a-new-pain-threshold-forbanks-838791 (last visited 2 January 2020).

101. McKinsey, above n. 95.

102. For more on banks' function as delegated monitors and their information advantage as compared with the market, see D.W. Diamond, 'Financial Intermediation and Delegated Monitoring', 51 The Review of Economic Studies 393 (1984) 
ky borrowers, because their amount of RWAs may be increased anyway. Additionally, when they inevitably choose to move some activities into the SBS, the risk will also rise, as 'shadow' operations are known to be more profitable and riskier at the same time. As a result, the whole banking system might actually become more, not less risky. ${ }^{103}$

In addition, the European banking system is known for having a very complex and fragmented structure. Not only are the disparities between Eurozone and nonEurozone Member States noticeable, but also the way of financing the economy in EU countries varies. The line can be drawn between 'The North' and 'The South'. Specifically, banks in the Netherlands and Sweden or Finland have their balance sheets full of mortgage loans that, under new rules, could cause an increase in required capital buffers. ${ }^{104}$ In contrast, southern banks from Portugal, Italy or Spain hold much more sovereign bonds, still considered to be risk free. Even though the northern banks claim to be able to absorb the impact of Basel IV, the differentiation in balance sheets across the EU will increase, also misleadingly pointing to the North as a riskier region. This could contribute to the deepening of the fragmentation of the EU banking system and jeopardise harmonisation efforts.

\subsubsection{More of Competitive Disadvantage Tomards the US}

The conflict of interest between the US and the EU (particularly France and Germany, homes of the biggest EU banks) was the main cause of the delay ${ }^{105}$ in completing Basel IV standards. After the new rules are implemented, European banks will be put at a significant competitive disadvantage in relation to their American counterparts for at least three reasons. First, the US economy is financed differently than the EU economy. In the US, almost $80 \%$ of financing comes from the capital markets in comparison with only $20 \%$ provided by the banks. In the EU, the statistics look exactly opposite - when a European entrepreneur wants to expand his business, he goes to the bank to get a loan, rather than issuing equity. Hence, the balance sheets of American banks are, in general, less leveraged and thus less risky. ${ }^{106}$ Second, the EU financial institutions have much fewer opportunities of securitisation than their US rivals, which leads to the situation that the loans remain on balance sheets. More loans obviously increase the amount of RWAs, and thus required capital. Also, EU banks overall are weaker because of the delayed

103. Sia Partners, above n. 101

104. Dutch banks estimate to have a 14-billion euro capital shortfall. See Bloomberg, above n. 96 .

105. Most of the changes were primarily proposed in March/April 2016, and even in October 2017 it was not certain whether the standards would be officially adopted. See C. Binham and J. Brunsden, 'France Hardens Stance Against Higher Bank Capital Requirements', Financial Times (10 October 2017), www.ft.com/content/ ee8f42eb-422a-3dc9-92a2-8ceb7d9fb4ef (last visited 2 January 2020).

106. Surprisingly, that was the case even before and during the global financial crisis. Deutsche Bank reached the level of 50. See M. Choudhry and G. Landuyt, The Future of Finance: A New Model for Banking and Investment (Wiley 2010), at 46-50. post-crisis recovery. When US banks were returning to profit levels that prevailed before the 2008 downturn, ${ }^{107}$ EU banks had to face the sovereign debt crisis. Lastly, the US regulators have already introduced the output floors, and even at the level of $100 \%$. Consequently, for the US banking sector it makes no difference what Basel IV rules prescribe on that matter. As the result of the foregoing factors, European banks will suffer under new Basel IV standards much more than the US institutions. The investors would logically tend to choose the latter entities over the former, knowing that US banks will not be forced to increase their capital buffers at the depositors' or shareholders' cost. ${ }^{108}$

\subsection{Basel IV - Implementation}

Originally, provisions of Basel IV were supposed to be implemented by 2022 with regard to risk and RWA calculations and output floor of $72.5 \%$ was to be achieved gradually by 2027. However, a new downturn came quicker than expected when the coronavirus epidemic forced whole nations into lockdown. Banks started to vocalise the problems described above, threatening that they would not have the capacity to support the real economy. ${ }^{109}$ It has become definitely visible how burdensome the additional buffers are. Regulators and supervisors all over the world started rolling back capital requirements and freeing capital in the fear that banks would not have enough resources to spend on lending. In EU, apart from the European Central Bank (ECB) capital-loosening actions, France, Germany and the Netherlands gave up on the countercyclical buffer. ${ }^{110}$ Also, the BCBS caved in and introduced measures that shall 'free up operational capacity for banks and supervisors as they respond to the economic impact of Covid-19'. ${ }^{111}$ Specifically, it postponed the implementation of Basel IV by one year, till the beginning of 2023. Even though it is highly improbable that the final shape of the Basel IV could be amended, this time until implementation could be wisely used by global regulators and supervisors to reconsider striking some balance between non-existent prudential rules on SBS and the constantly growing body of standards applicable to TBS.

107. J. Lybeck, The Future of Financial Regulation. Who Should Pay for the Failure of American and European Banks? (Cambridge University Press 2016), at 116.

108. D. Masoni, 'Regulatory Angst Curbs Investor Appetite for European Banks', Reuters (5 December 2017), www.reuters.com/article/useurope-banks-capital-analysis/regulatory-angst-curbs-investorappetite-for-european-banks-idUSKBN1DZ28S (last visited 2 January 2020).

109. D. Crow, S. Morris \& L. Noonan, 'Banks Plead for Rethink Over PostCrisis Rules,' Financial Times (19 March 2020), www.ft.com/content/ 0827a58e-693d-11ea-800d-da70cff6e4d3 (last visited 15 April 2020).

110. www.ft.com/content/9a677506-a44e-4f69-b852-4f34018bc45f? desktop=true\&segmentld=d8d3e364-5197-20eb-17cf-2437841d178a\# myft:notification:instant-email:content.

111. BCBS Press Release, Governors and Heads of Supervision announce deferral of Basel III implementation to increase operational capacity of banks and supervisors to respond to Covid-19, 27 March 2020, www.bis.org/press/p200327.htm (last visited 15 April 2020). 


\begin{tabular}{|c|c|c|c|}
\hline $\begin{array}{l}\text { Basel IV } \\
\text { novelty }\end{array}$ & PROS & CONS & Overall assessment \\
\hline $\begin{array}{l}\text { SA for } \\
\text { credit risk } \\
\text { of certain } \\
\text { exposures }\end{array}$ & $\begin{array}{l}\text { - Comparability (level playing field) } \\
\text { - Less risk of gaming the calculation } \\
\text { - Differences between exposures' charac- } \\
\text { ter taken into account }\end{array}$ & $\begin{array}{l}\text { - Less accuracy } \\
\text { - Capital shortfalls resulting } \\
\text { in indirect increase in capi- } \\
\text { tal requirements }\end{array}$ & $\begin{array}{l}\text { - Useful, if determined individually } \\
\text { for each of institutions, taking into } \\
\text { account its business model } \\
\text { - Alternative: more supervisory input } \\
\text { in IRB }\end{array}$ \\
\hline $\begin{array}{l}\text { SA for } \\
\text { opera- } \\
\text { tional risk }\end{array}$ & $\begin{array}{l}\text { - Comparability (level playing field) } \\
\text { - Less risk of gaming the calculation }\end{array}$ & $\begin{array}{l}\text { - Less accuracy (very impor- } \\
\text { tant with op risk, given } \\
\text { how institution-specific it is) } \\
\text { - Capital shortfalls resulting } \\
\text { in indirect increase in capi- } \\
\text { tal requirements }\end{array}$ & $\begin{array}{l}\text { - Useful, if determined individually } \\
\text { for each of institutions, taking into } \\
\text { account its business model } \\
\text { - Alternative: more supervisory input } \\
\text { in IRB }\end{array}$ \\
\hline $\begin{array}{l}\text { Leverage } \\
\text { ratio add- } \\
\text { on for G- } \\
\text { SIBs }\end{array}$ & $\begin{array}{l}\text { - Completion of the G-SIB specific frame- } \\
\text { work (after G-SIB capital add-on) }\end{array}$ & $\begin{array}{l}\text { - Depending on pretty arbi- } \\
\text { trary G-SIB designation } \\
\text { - Incentive to take on more } \\
\text { risk }\end{array}$ & $\begin{array}{l}\text { - Necessary adjustment taking into } \\
\text { account systemicness of banks }\end{array}$ \\
\hline $\begin{array}{l}\text { Output } \\
\text { floor }\end{array}$ & $\begin{array}{l}\text { - Final backstop preventing banks from } \\
\text { too low RWA result }\end{array}$ & $\begin{array}{l}\text { - } \text { Arbitrary } \\
\text { - } \text { Half of the capital shortfall } \\
\text { stems from it } \\
\text { - } \text { Incentive to take on more } \\
\text { risk }\end{array}$ & $\begin{array}{l}\text { - Arbitrary } \\
\text { - Unnecessary in the presence of } \\
\text { adequately formulated SA }\end{array}$ \\
\hline
\end{tabular}

\section{Recommendations and Conclusion}

It is not disputed that risks and vulnerabilities are an inherent characteristic of the SBS, especially considering that the SBS was central to the global crisis of $2008 .^{112}$ One therefore has to wonder why the further tightening of the TBS through the recent Basel IV was introduced rather than efforts to dampen the inherent systemic risks within the SBS. ${ }^{113}$ Nevertheless, Basel IV has been introduced, which has created further negative implications, especially with regard to profitability by putting EU banks at a competitive disadvantage in relation to US institutions. Also, a further increase in capital requirements caused by the amendments in calculation models will adversely impact EU banking institutions, and they will look for a path to circumvent it. As such, the incentive for EU banks to continue to migrate their activities into the shadows could not be more profound.

Could the postponement of Basel IV implementation be seen as a chance to fill the loophole of SBS regulation? Could the institutions focused on combating economic

112. Financial Stability Board, 'Global Shadow Banking Monitoring Report 2017', (5 March 2018), www.fsb.org/wp-content/uploads/ P050318-1.pdf (last visited 2 January 2020)

113. For an in-depth analysis of the potential regulatory solutions of nonbank SIFIs, see D. Busch and M.B.J. van Rijn, 'Towards Single Supervision and Resolution of Systemically Important Non-Bank Financial Institutions in the European Union', 19(2) European Business Organization Law Review 301 (2018). externalities of Covid-19 pandemic also formulate provisions for this omitted sector? Of course, while regulation is necessary from a financial stability perspective, the flip side is that over-regulation can have the perverse effect of limiting profitability and stifling innovation (or it can be rolled back quickly once the crisis strikes, as we can see it now). However, various commentators remain sceptical that the SBS can ever be comprehensively regulated. For example, some hold that the SBS is far too diverse to be regulated effectively, while others argue that regulatory efforts consistently fail to catch up with new developments. ${ }^{114}$ Adding to these comments, crucially, there is also a severe lack of granular data within the SBS. ${ }^{115}$ Obviously, it is very difficult to regulate something you do not know a huge amount about, and, of course, we do not know what the SBS will look like in the future in view of to its complexity, diversity and constantly evolving nature. ${ }^{116}$ Supervisory bodies, such as the FSB,${ }^{117}$ the European

114. S. Claessens and L. Kodres, 'The Regulatory Responses to the Global Financial Crisis: Some Uncomfortable Questions', IMF Working Paper 14/46 6 (2014), www.imf.org/external/pubs/ft/wp/2014/wp1446.pdf (last visited 2 January 2019). See also, Davies, above n. 65.

115. J. Mazzacurati, 'Haircuts in EU Securities Financing Markets', ESMA Report on Trends, Risks and Vulnerabilities 52, at 52 (2017).

116. H. Nabilou and A.M. Pacces, 'The Law and Economics of Shadow Banking', in I.H.Y. Chiu and I.G. MacNeil (eds.), Research Handbook on Shadow Banking Legal and Regulatory Aspects (2018) 7.

117. There have been a host of publications by the FSB on the SBS, the most recent being the FSB's 'Global Shadow Banking Monitoring Report 2017', (n. 112) 
Securities and Markets Agency (ESMA) ${ }^{118}$ and the European Systemic Risk Board (ESRB) ${ }^{119}$ have introduced numerous publications on the issue of regulating the SBS, but the fact remains that it is an issue yet to be substantially tackled. The results to date are no greater than piecemeal solutions. It is unfortunate that supervisors and regulators alike do not seem to be tackling this problem head on. But one thing is for sure, and perhaps this answers why the focus has not been turned to the SBS - if it were to be regulated to the similar severity of the TBS, then, by default, the SBS will likely circumvent those rules and find alternative ways of engaging in financial markets - which could, we think, lead us back down the familiar dark path of 2007.

The authors would like to introduce three plausible policy recommendations that may be useful in the quest to appropriately regulate the SBS.

\subsection{Recommendation 1}

Before even considering the gargantuan task of regulating the SBS, the first logical recommendation would be to concentrate on gathering sufficient data because it is impossible (and ineffective) to regulate something without any. By imposing more stringent reporting requirements on entities, activities and transactions will ultimately create a more comprehensive image of what effective and targeted regulation should look like. ${ }^{120}$

\subsection{Recommendation 2}

The second recommendation is the possible regulation of liquidity within the SBS. Within the TBS, liquidity is an issue comprehensively regulated under the LCR and the NSFR. Within the SBS, the use of FC and the liquidity of those assets is left for market participants to decide. The general idea is that as long as the parties are in agreement about what securities are used as collateral, it can be used as cash equivalent. Of course, this is dangerous given that many financial securities are highly volatile and subject to frequent and unpredictable intraday price fluctuations.

The authors recommend that collateral liquidity should be regulated by way of a minimum liquidity cap. This would mean that only certain predefined assets can be used to secure a collateralised transaction commonly used in the SBS-assets such as cash or highly rated debt, namely Aaa government bonds or investment grade corporate bonds, for example. ${ }^{121}$

Since the global financial crisis, the assets posted as collateral have, in general, taken a 'flight to quality'. In practice, liquidity and the promise of cash immediacy are paramount when determining what is deemed 'cash equivalent'. The BCBS/IOSCO and the RTS have helpfully provided EU market participants with an informative list, which outlines the most liquid and safest forms of collateral assets used to secure specific derivatives transactions: ${ }^{122}$

- Cash;

- High-quality government and central bank securities;

- High-quality corporate bonds;

- High quality covered bonds;

- Equities included in major indices; and

- Gold.

To be 'eligible', the asset must meet the criteria negotiated and documented in the ISDA Master Agreement Credit Support Annex, e.g. which currencies the FC may be in, what types of bonds/assets are allowed and which haircuts are to be applied. ${ }^{123}$ Generally, cash in the form of \$USD, £GBP, €Euro and ¥Yen and highly rated government securities of the USA, Canada, the Netherlands, Germany, UK, France and Belgium are the most liquid and therefore the most sought after form of Eligible Credit Support. ${ }^{124}$ Depending on which form of assets are used, the general rule is that as long as the assets are liquid, can be valued mark-to-market and meet the necessary regulatory requirements, and as long as the parties are in agreement, the asset can be used as cash equivalent. ${ }^{125}$

However, this matrix applies only to certain derivatives transactions, not to all collateralised financial transactions - namely repos and securities lending. The authors propose to develop this collateral matrix by recommending that it applies to all collateralised transactions. Any assets that do fall within these criteria would become 'ineligible', and the collateral taker would therefore have to notify the collateral giver, by delivering a 'Legal Ineligibility Notice' outlining, among other things, the reasons why the assets do not fulfil the eligibility requirements. ${ }^{126}$
118. The ESMA has also introduced numerous publications on shadow banking; for the most recent see: 'ESMA Reports on Shadow Banking, Leverage and Pro-cyclicality', (2016), www.esma.europa.eu/press-news/ esma-news/esma-reports-shadow-banking-leverage-and-pro-cyclicality (last visited 2 January 2020).

119. The most recent ESRB publication on shadow banking is: ESRB 'Macroprudential Use of Margins and Haircuts', (2017), www.esrb.europa.eu/ pub/pdf/reports/

170216_macroprudential_use_of_margins_and_haircuts.en.pdf (last visited 2 January 2020).

120. Arts. 4 and 12 of the SFTR have reporting obligations - however, it is currently uncertain how effective these provisions are given that ESMA have recently issued a consultation on the matter. See ESMA, 'Consultation on Guidelines for Reporting Under Articles 4 and 12 SFTR', (29 July, 2019), www.esma.europa.eu/press-news/consultations/ consultation-guidelines-reporting-under-articles-4-and-12-sftr.
121. Of course, the list is not finite.

122. Basel Committee on Banking Supervision and the Board of the International Organization of Securities Commissions, 'Margin Requirements for Non-centrally Cleared Derivatives', 1, at 17-18 (March, 2015), www.bis.org/bcbs/publ/d317.pdf. See also Art. 4 of the RTS, which provides a comprehensive list of eligible collateral types.

123. Paras. 10 and 11(b)(ii), 1995 ISDA English Law CSA and Paragraphs 10 and 11(c)(ii), 2016 English Law CSA for Variation Margin.

124. See also, P.C. Harding and A.J. Harding, A Practical Guide to the 2016 ISDA Credit Support Annexes for Variation Margin (2018) Authors' Foreword xi.

125. Yeowart, Parsons, Murray \& Patrick, above n. 22, at 64-65. See also, Singh, above n. 23, IMF Working Paper 1, at 5.

126. Paras. 9(e)-(h) and 11(c)(iii), 2016 English Law CSA for Variation Margin. 


\subsection{Recommendation 3}

The third recommendation of regulating the SBS is by limiting the amount of leverage an institution can hold this can be done by minimum margin regulation. Within the SBS, leverage levels can, theoretically, be infinite. Collateralised transactions facilitate leverage by enabling financial institutions to borrow securities or cash 'to make leveraged bets on an already leveraged instrument'. ${ }^{127}$ To build such positions, the Bank for International Settlements has noted that in repos, for example, "market participants use cash raised through an initial repo transaction to buy securities which, in turn, are repoed out to raise more cash to buy more securities and so on... [ad infinitium]." With each transaction the leverage ratio increases because the re-use/rehypothecation of collateral allows market participants to recursively leverage their positions, implying that there could, theoretically, be infinite amounts of leverage. ${ }^{128}$

Prudentially regulated banks have comprehensive regulation with regard to the amount of leverage they are allowed to hold through Basel III's minimum leverage ratio. ${ }^{129}$ The European Markets Infrastructure Regulation (EMIR) has also made real progress in the OTC derivatives markets by increasing the use of central clearing. Article 41 of the EMIR requires central counterparties to impose, call and collect margin. Furthermore, the Regulatory Technical Standards 153/2013 (RTS) provides alternative options linked to procyclicality, leverage and margin. ${ }^{130}$ In particular, both the RTS and the EMIR are designed to limit the build-up of leverage in OTC derivatives markets that are subject to central clearing.

AIFMs also have a leverage framework under the Alternative Investment Fund Managers Directive (AIFMD). ${ }^{131}$ As part of their risk management process, AIFMs set a maximum level of leverage that they may employ on behalf of every alternative investment fund (AIF) they manage, as well as the extent of the collateral reuse right that could be granted under the leveraging arrangement. ${ }^{132}$

Reforms in other areas, such as the SFTR and the UCITS, however, have been less convincing. Under the SFTR, where repos and securities lending transactions play a central role, the substantive progress made on leverage and the use of margin is debatable. ${ }^{133}$ The same is true of the guidelines published by the ESMA on issues related to the UCITS, which specify the requirements around efficient portfolio management and risk management processes in greater detail. In particular, the use of collateral and the requirements for 'conservative' haircuts. ${ }^{134}$

Yet the reciprocal of leverage is margin. ${ }^{135}$ This means that, in practice, infinite leverage comes up against a significant problem - margin. Margin requirements applied to any given collateralised transaction ensure that leverage can be limited - this holds true provided that market participants cannot fund their margin requirements through unsecured borrowing. ${ }^{136}$ Markus Brunnermeier notes that because the collateral giver must finance margin with its own capital, it is not possible to borrow the amount equal to the market value of the collateral. ${ }^{137}$ For instance, when a financial institution, such as a hedge fund, enters into a repo transaction and uses Aaa Dutch government bonds as collateral, it must negotiate, among other things, ${ }^{138}$ the amount of cash that it can ultimately borrow, ${ }^{139}$ if the posted collateral is worth $€ 100$ and the cash received is $€ 80$, then the initial margin/haircut is $120 \% / 20 \%$, the loan to value ratio is $€ 80 / € 100=80 \%$ and the leverage ratio 5:1. These ratios are all synonymous. In other words, margin requirements determine the maximum amount that a party can borrow when using a given security as collateral. ${ }^{140}$ In light of the fact that leverage lies at the heart of many past financial crises, ${ }^{141}$ the authors propose the adoption of minimum margin regulation to

127. Cullen, above n. 3, at 93-94

128. Bank for International Settlements, 'Repo Market Functioning', CFGS Paper No. 59 1, at 6 (2017). See also, Cullen, above n. 3, at 93-94; European Systemic Risk Board, 'ESRB Opinion to ESMA on Securities Financing Transactions and Leverage Under Article 29 of the SFTR', 1, at 5 (October 2016); P.C. Harding and C.A. Johnson, A Practical Guide to Using Repo Master Agreements (2017), at 14

129. Basel Committee on Banking Supervision, above n. 6, 1 at 140. See also, Art. 429 of Regulation (EU) No 575/2013 of the European Parliament and of the Council of 26 June 2013 on prudential requirements for credit institutions and investment firms and amending Regulation (EU) No 648/2012 (CRR); Art. 87 of Directive 2013/36/EU of the European Parliament and of the Council of 26 June 2013 on access to the activity of credit institutions and the prudential supervision of credit institutions and investment firms, amending Directive 2002/87/EC and repealing Directives 2006/48/EC and 2006/49/EC (CRD); pages 16 and 17 of Chapter 1.

130. Commission Delegated Regulation (EU) No 153/2013 of 19 December 2012 supplementing Regulation (EU) No 648/2012 of the European Parliament and of the Council with regard to RTS on requirements for central counterparties, L 52, OJ 23.2.2013, page 41.

131. Directive 2011/61/EU of the European Parliament and of the Council of 8 June 2011 on Alternative Investment Fund Managers and amending Directives 2003/41/EC and 2009/65/EC and Regulations (EC) No 1060/2009 and (EU No 1095/2010) (AIFMD)

132. Arts. $15(4)$ and 25 of the AIFMD.

133. European Securities and Markets Authority, 'Report on Securities Financing Transactions and Leverage in the EU', ESMA/2016/1415, 1, at 37-39 (2016), www.esma.europa.eu/sites/default/files/library/ 2016-1415_-_report_on_sfts_procyclicality_and_leverage.pdf.

134. Ibid.

135. J. Geanakoplos, 'The Leverage Cycle', $1715 R$ Cowles Foundation Discussion Paper 2010:1, at 1-2.

136. European Systemic Risk Board, 'The Macroprudential Use of Margins and Haircuts', 1, at 25 (2017)

137. M.K. Brunnermeier, 'Deciphering the Liquidity and Credit Crunch 2007-2008', 23(1) Journal of Economic Perspectives 77, at 91-92 (2009). See also, European Systemic Risk Board, above n. 138.

138. For example, the interest rate.

139. Or any other form of shadow bank, such as an insurance company, pension fund, investment fund, etc.

140. Constancio, above n. 60.

141. Such as the Wall Street crash of 1927-1929, the Japanese banking crisis of 1991, the financial derivatives crisis in 1994 that bankrupted Orange County in California, the 1998 emerging markets mortgage crisis that collapsed Long-Term Capital Management, the more recent 2008 global financial crisis. See, M. Schularick and A.M. Taylor, 'Credit Booms Gone Bust: Monetary Policy, Leverage Cycles, and Financial Crises, 1870-2008', 102(2) American Economic Review 1029-1061 (2012). 
mitigate the procyclical effects that follow through the cycle leverage and liquidity spirals. ${ }^{142}$

Before comprehensive data on SBS is gathered and, on its basis, liquidity and margin aspects are regulated, there will always remain a loophole in the financial regulation that slowly, but steadily, undermines the achievements of TBS-oriented prudential rules.

142. Pacces and Nabilou, above n. 10. See also, Constancio, above n. 60; European Systemic Risk Board, above n. 138; Bank for International Settlements, above n. 129; Brunnermeier, above n. 138, at 77; Cullen, above n. 3; J. Geanakoplos and L.H. Pedersen, 'Monitoring Leverage', in M. Brunnermeier and A. Krishnamurthy (eds.), Risk Topography: Systemic Risk and Macro Modeling (2014), at 113; Financial Stability Board (Press Release), 'FSB Adjusts Implementation Timelines for Its Policy Recommendations to Address Financial Stability Risks in Securities Financing Transactions', (19 July, 2019). https://www.fsb.org/ 2019/07/fsb-adjusts-implementation-timelines-for-its-policy-recommendations-to-address-financial-stability-risks-in-securities-financingtransactions/. 